Research.

\title{
AN ANALYSIS OF THE INFLUENCE OF AUDIT CAPACITY STRESS, SIZE OF THE COMPANY AND THE INDEPENDENCE OF AUDIT COMMITTEE UPON AUDIT QUALITY AT COMPANY BANKING LISTED ON BEI (INDONESIA STOCK EXCHANGE) FOR THE PERIOD OF 2012 - 2016
}

\author{
Asna Manullang \\ STIE Binaniaga, Bogor, Indonesia
}

\begin{abstract}
Received: January 27, 2018; Accepted: April 15, 2018; Published: June 30, 2018
To cite this article: Asna Manullang, An Analysis of The Influence of Audit Capacity Stress, Size of The Company and The Independence of Audit Committee Upon Audit Quality at Company Banking Listed on BEI (Indonesia Stock Exchange) for The Period of 2012 - 2016, The Accounting Journal of BINANIAGA, Vol. 03, No. 01, June 2018, pp. 15 - 24.
\end{abstract}

Abstract. The objective of this research is to find out and to analyze the influence of audit capacity stress, size of the company and the independence of audit committee upon audit quality (empiric study at company banking listed on BEI period of 2012 2016).

The result of this research has shown that audit capacity stress, size of the company and the independence of audit quality had not significantly influenced audit quality of company banking listed on BEl.

Keywords: Audit Capacity Stress, Size of the company, The Independence of Audit Committee, Audit Quality.

\section{INTRODUCTION}

\section{A. Problems Background}

An Audit is the process of reducing any incompliance information happened between the managers of the company and the stakeholders using external party to legalize its financial reporting. Users of the financial report especially the investors and stakeholders will make a decision according to the financial reports audited and provided by the auditors obviously. It explains that auditors have a very important role to conform financial reports of the company. The perception of audit quality service issued by KAP (Public Accountant Office) will be very much useful for the investors and users of the financial report. Therefore, ability to provide best quality of an audit service has become the focus of KAP (Public Accountant Office). An audit which has been done effectively will create the quality of financial report, relevant and reliable.

\section{B. Problems Design}

Based on the problems background above, the writer has formulated the following study;

1. Is audit capacity stress at company banking influencing significantly the quality of an audit?

2. Is the size of company at company banking influencing significantly the quality of audit? 
3. Is the independency of audit committee at company banking influencing the quality of audit?

\section{Objective of The Research}

Objective of this research is a result of the research achievable and is consistent with the problems and questions indicatede on the problems design above. However, the objectives of the research are as follows:

1. To get an empirical evidence describing that audit capacity stress has significantly influenced the audit quality.

2. To obtain an empirical evidence describing that the size of company has significantly influenced the audit quality.

3. To get an empirical evidence describing that the independence of audit committee has significantly influenced the audit quality.

\section{THEORY REVIEW}

\section{A. Relevant Concept and Theory}

\section{Compliance Theory}

Compliance theory is a guidance about time punctuality to send the financial report of Indonesia public company which has been regulated in the Obedience Letter of the Chief BAPEPAM No. Kep-36/PM/2003 regarding the obligation to send the financial report periodically

\section{Signalling Theory}

Referring to Jama'an (2008) Signalling theory has defined about how a company should have given a signal to the users of financial reports. Nevertheless, Brigham and Houston said that a signal is an action done by a company to provide a guideline for the investors about how the management has been learning the prospect of the company. Such a signal is the information regarding what the management has been doing to make the owner intention come true. The signal can be a promotion or other information describing the related company is a better company than the others.

\section{Audit Quality}

Quality is the right professional components which is the best one to be kept by professional public accountant. Independent accountant means that public accountant should have put priority the public requirement rather than management or auditor requirement itself preparing auditing report. The quality of audit is having varied meanings. According to Auditor's perception, audit quality is the output of auditors' job which is in compliance with the applicable standards and professional code of ethics.

\section{Size of Public Accountant Office}

Public Accountant Office is an organization of public accountants that is holding the permits which is in compliance with the applicable regulations regarding professional services of public accountant practices (Rachmawati, 2008).

\section{Audit Capacity Stress}

Audit capacity stress is the pressure received by the auditors (AP) in relation with a lot of audit clients requirements that should have to be done accordingly. Beginning of the year is the busiest time of auditor to execute an 
audit. Referring to some researches, audit capacity stress can be defined an overload job.

\section{Independence of Audit Committee}

According to the Regulation of Bapepam-LK No. IX.1.5 No. Kep643/BL/2012 regarding Audit Committee, Audit committee is a committee appointed by board of commissioners and is reporting to them to support their tasks and functions. Audit committee is independently doing its job which is consisting of 3 persons minimum who are from independent commissioners and external party of the company or public company.

\section{B. Framework Design}

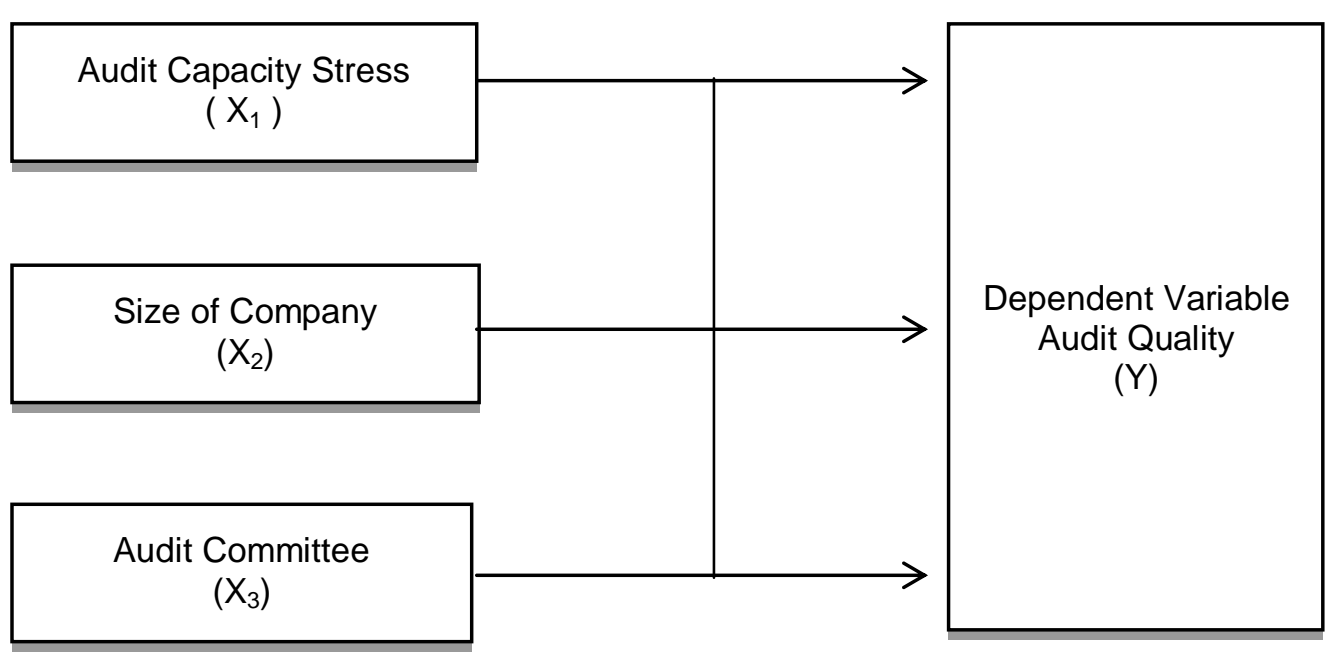

Figure 1.

Conceptual Framework

Independent variables of this research are audit capacity stress, size of company and independence of audit committee. And dependent variable is audit quality. Referring to correlation of the related variables, this research has applied compliance theory, signalling theory.

\section{Hypothesis of The Research}

$\mathrm{H}_{1}$ : Audit Capacity Stress has significantly influenced Audit quality.

$\mathrm{H}_{2}$ : Size of company has significantly influenced audit quality

$\mathrm{H}_{3}$ : Independence of Audit committee has significantly influenced audit quality

$\mathrm{H}_{4}$ : Percentage of the effect of audit capacity stress, independence of audit committee and size of company simultaneously have influenced audit quality.

\section{RESEARCH METHODOLOGY}

\section{A. Research Method}

This research is a causal-comparative research. According to Suryabrata (2012:84) causal-comparative research is a research studying the probability of cause effect connection based on the observation upon an existing effect factor using specific data that could find the reason why such an effect has happened.

Asna Manullang: An Analysis of The Influence of Audit Capacity Stress, Size of The Company and The Independence of Audit Committee Upon Audit Quality at Company Banking Listed on BEI (Indonesia Stock Exchange) for The Period of 2012 - 2016 


\section{B. Population and Sample of the Research}

Population of this research are General Banks which have been 'going public' during the observation period of 2012 - 2016 which is 41 companies. Selection and collection of the sample of companies have applied purposive sampling approach.

\section{Type and Data Resource}

The data being used in this research is secondary data. However, the data required for this research is annual financial report for the period of $2012-2016$. Resource of the data is the company's financial report obtained from the website www.idx.co.id and ICMD (Indonesia Capital Market Directory).

\section{Technique of Data Analysis Applied}

\section{Descriptive Statistics}

Descriptive statistic is a statistic describing an object that has been studied thru the available data of the sample or population without doing any analysis and defining a conclusion which is applicable for the public.

\section{Logistics Regression Analysis}

Logistic regression analysis is required to disclose the probability of dependent variable which can be predicted by independent variable, and the research model is as follows:

$$
A Q=b_{0}+b_{1} A C S+b_{2} S I Z E+b_{3} C O M+e
$$

\section{Evaluating Regression Model (Goodness of Fit).}

If the statistical value of Hosmer and lemeshow's goodness of fit test is the same with or less than 0.05 , then hypothesis 0 is rejected. However, if its value is more than 0.05 , then hypothesis 0 is not rejected, it means that such the model is able to predict the observation value or it is fit with the data.

\section{E. Hypothesis Test}

$\mathrm{H}_{\mathrm{o}}$ is accepted if Wald calculated < Chi-Square table, and the value of Asymptotic Significance $>$ sig.value ( $\alpha$ ). It means that alternative $\mathrm{H}$ is rejected or the hypothesis describing independent variable has been affecting dependent variable is rejected.

$\mathrm{H}_{\mathrm{a}}$ is accepted if Wald calculated $>$ Chi-Square table, and Asymptotic Significance value < sig.value (a). It means that alternative $\mathrm{H}$ is accepted or the hypothesis declaring that independent variable has been affecting dependent variable is accepted.

\section{RESULT AND DESCRIPTION OF THE RESULT}

\section{A. General Information of the Company}

This research has applied the object of the research which is company banking listed on the Indonesia Stock Exchange (BEI) during the research period of 2012 2016. Focus of the research is about the effect of audit capacity stress, size of the company and independence of audit committee upon audit quality at company banking.

Numbers of company banking listed on the Indonesia Stock Exchange for the period of $2012-2016$ is 41 (forty one) companies. 


\section{B. Description of the Sample of Research}

This research has applied purposive sampling method to select the sample.

\section{Result of the Research}

\section{Descriptive Statistics}

Descriptive statistics is applied to describe the data referred to its mean, median, standard deviation, minimum value and maximum value (Lutfi and Situmorang, 2012).

Table 1.

(Descriptive Statistic)

\begin{tabular}{|l|c|r|r|r|r|}
\hline & $\mathrm{N}$ & Minimum & Maxsimum & Mean & $\begin{array}{c}\text { Std. } \\
\text { Devitiation }\end{array}$ \\
\hline AQ & 120 & 0 & 1 & .73 & .448 \\
\hline ACS & 120 & 2 & 134 & 61.65 & 26.052 \\
\hline SIZE & 120 & 28 & 35 & 31.22 & 1.676 \\
\hline COM & 120 & .13 & .33 & .2799 & .06222 \\
\hline Valid N (listwise) & 120 & & & & \\
\hline
\end{tabular}

Resource : www.idx.co.id (data processed : output of SPSS 21)

Test result of descriptive statistic above has been describing as follows:

a. Result of analysis applying descriptive statistics upon audit quality (AQ) has indicated minimum value of 0 , maximum value of 1 and its mean of 0.73 and standard deviation of 0.448 .

b. Result of analysing applying descriptive upon audit capacity stress (ACS) has indicated minimum value of 2, maximum value of 134 and its mean of 61.65 and standard deviation of 26.052.

c. Result of analysis applying descriptive upon size of the company has indicated minimum value of 28 , maximum value of 35 and its mean of 31.22 and standard deviation of 1.676 .

d. Result of analysis applying descriptive upon independence of audit committee (COM) has indicated minimum value of 0.13 , maximum value of 0.33 and its mean of 0.2799 and standard deviation of 0.06222 .

\section{Result of Hypothesis Test}

a. Goodness of Fit Test

Table 2.

Omnibus Tests of Model Coefficients

\begin{tabular}{|l|l|r|c|c|}
\hline \multicolumn{2}{|l|}{} & Chi-square & Df & \multicolumn{1}{c|}{ Sig. } \\
\hline Step 1 & Step & 35.099 & 3 & .000 \\
\hline & Block & 35.099 & 3 & .000 \\
\hline & Model & 35.099 & 3 & .000 \\
\hline
\end{tabular}

Resource : www.idx.co.id (Output data processed SPSS 21)

Asna Manullang: An Analysis of The Influence of Audit Capacity Stress, Size of The Company and The Independence of Audit Committee Upon Audit Quality at Company Banking Listed on BEI (Indonesia Stock Exchange) for The Period of 2012 - 2016 
1) Sig Omnibus $\leq 0.05=$ Logistic Regression Model is applicable

2) Decision : Logistic Regression Model is applicable since Sig. Omnibus $(0.000)$ is less than Alpha $(0.05)$

\section{b. Applicable Regression Model Test}

Table 3.

Applicable Regression Model Test Hosmer and Lemeshow Test

\begin{tabular}{|r|r|r|l|}
\hline Step & $\begin{array}{c}\text { Chi- } \\
\text { square }\end{array}$ & \multicolumn{1}{c|}{ Df } & \multicolumn{1}{c|}{ Sig. } \\
\hline 1 & 16.870 & 8 & .031 \\
\hline
\end{tabular}

Resource : SPSS 21 Output

Result of analysis on table 3 has indicated the value of .031 it means that its significance is more than 0.05 , so that this model can be concluded is able to predict its observation value accordingly.

c. Multicoliniearity Test

Table 4

Multicoliniearity Test

\begin{tabular}{|l|l|r|r|r|r|}
\hline \multicolumn{7}{|c|}{ Coleration Matrix } \\
\hline & & Constant & ACS & SIZE & COM \\
\hline Step 1 & Constant & 1.000 & .050 & -.980 & -.620 \\
\hline & ACS & .050 & 1.000 & -.105 & -.104 \\
\hline & SIZE & -.980 & -.105 & 1.000 & .464 \\
\hline & COM & -.620 & -.104 & .464 & 1.000 \\
\hline & & & & & \\
\hline
\end{tabular}

Resource : SPSS 21 Output

Ghozali (2006), if there is sufficient correlation among the independent variables which is higher than 0.90 , it has indicated multicoliniearity has happened. Result of analysis has indicated that there is not any correlation coefficient value of independent variables which is more than 0,90 , it is concluded that there is not any multicoliniearity indicated among the independent variables.

\section{d. Description of Rhe Result of Hypothesis Test}

Based on the logistic regression test which has been described above, the interpretation of the results has been provided into three parts.

1) The Effect of Audit Capacity Stress (ACS) upon Audit Quality (AQ)

Asna Manullang: An Analysis of The Influence of Audit Capacity Stress, Size of The Company and The Independence of Audit Committee Upon Audit Quality at Company Banking Listed on BEI (Indonesia Stock Exchange) for The Period of 2012 - 2016 
ACS variable has indicated positive regression coefficient of 0.013 and its significance $(p)$ of 0.155 , which is more than $\alpha=5 \%$. Since its significance level $(p)$ is more than $\alpha=5 \%$, however first hypothesis is not supported. This research has failed to prove that audit capacity stress has affected audit quality.

\section{2) The Effect of Size of company upon Audit Quality (AQ)}

SIZE variable has indicated positive coefficient of 0.863 and its significance $(p)$ of 0.000 , which is less than $\alpha=5 \%$. Since its significance level $(p)$ is less than $\alpha=5 \%$, so that, the second hypothesis is supported. Nevertheless, this research has proved that Size of company (SIZE) has affected Audit Quality

3) The Effect of Independence of Audit Committee (COM) upon Audit Quality (AQ)

COM variable has indicated a negative regression coefficient of 0.743 and its significance level $(p)$ is more than $\alpha=5 \%$. Since significance level $(p)$ is more than $\alpha=5 \%$, however the third hypothesis is unable to be supported. This research has failed to prove that independent audit committee has affected Audit Quality.

\section{CONCLUSION AND SUGGESTIONS}

\section{A. Conclusion}

.The Analysis conducted has applied logistic regression analysis using the program of Statistical Package for Social Sciences (SPSS) Ver. 21. Sample data of the company is 120 companies banking listed on the BEI years of $2012-2016$.

Based on the data analysis and the description above, the following conclusions are:

1. Result of the analysis of logistic regression has indicated that statistically audit capacity stress did not significantly affect Audit Quality on company banking during 2012 - 2016

2. Result of analysis of logistic regression has indicated that statistically size of the company has significantly affected audit quality at company banking during 2012 up to 2016.

3. Result of analysis of logistic regression has indicated that statistically independence of audit committee has not significantly affected audit quality at company banking during 2012 - 2016

\section{B. Suggestions} follows.

Based on the conclusion above, however some suggestions offered is as

In order to increase the investor's trustworthy, the company should have to be able to select the auditors who are having good reputation in order to get quality of an audit and to create the value of the company which is the information offered is accurate, reliable and transparent for the purpose of investors to get real condition regarding the prospect of the company in the future. 


\section{REFERENCES}

Al-Thuneibat, Ibrahim Isa, and Ata Baker, 2011. "Do audit tenure and firm size contribute to audit quality?". Journal of Accounting and Economics, Jordan.

Ardianingsih, Arum, 2014. "Pengaruh komite audit, lama perikatan audit, dan audit capacity stress terhadap kualitas audit. Jurnal Ekonomi Vol. 1 (1), Universitas Unikal.

Arens, Lobbecke, 2009. Auditing, Terjemahan: Amir Abadi Jusuf, Auditing pendekatan terpadu, Salemba Empat, Jakarta.

Brealey, Richard A., Stewart C. Myers, dan Alan J. Marcus, 2007. Dasar-dasar manajemen keuangan perusahaan, Jilid 2, Erlangga, Jakarta.

Febriyanti, Ni Made Dewi, dan I Made Mertha, 2014. "Pengaruh masa perikatan audit, rotasi kap, ukuran perusahaan klien, dan ukuran kap pada kualitas audit." EJurnal Akuntansi, Universitas Udayana.

IAPI, 2010. Directory 2010 Kantor Akuntan Publik dan Akuntan Publik. Jakarta.

IAPI, 2011. Directory 2011 Kantor Akuntan Publik dan Akuntan Publik. Jakarta.

IAPI, 2012. Directory 2012 Kantor Akuntan Publik dan Akuntan Publik. Jakarta.

IAPI, 2013. Directory 2013 Kantor Akuntan Publik dan Akuntan Publik. Jakarta.

IAPI, 2014. Directory 2014 Kantor Akuntan Publik dan Akuntan Publik. Jakarta.

IAPI, 2007. Standar Akuntansi Keuangan, Salemba Empat, Jakarta.

Jackson, A. B., Moldrich, M., Roebuck, P. 2010. "Mandatory audit firm rotation and audit quality". Rochester, Rochester.

Jensen, M. C., dan W. H. Meckling, 1976. Theory of The Firm: Managerial behavior agency costs and ownership structure, Journal of Financia Economics $3(4): h$ : 305-360.

Kementerian Keuangan RI, 2008. Peraturan Menteri Keuangan Nomor : 17/Pmk/01/2008 tentang Jasa Akuntan Publik.

Kementerian Keuangan RI. Keputusan Menteri Keuangan Republik Indonesia Nomor: 359/Kmk.06/2003, Tentang Perubahan Atas Keputusan Menteri Keuangan Nomor: 359/Kmk.06/2003.

Keputusan Ketua Badan Pengawas Pasar Modal Nomor: KEP-20/PM/2002 Peraturan Nomor VIII.A.2 Tentang Independensi Akuntan yang Memberikan Jasa Audit di Pasar Modal.

Keputusan Ketua Badan Pengawas Pasar Modal Nomor: KEP-34/PM/2003 Peraturan Nomor VIII.A.1 Tentang Pendaftaran Akuntan yang Memberikan Jasa Audit di Pasar Modal.

Keputusan Menteri Keuangan Republik Indonesia. Nomor: 359/Kmk.06/2003, Tentang Perubahan Atas Keputusan Menteri Keuangan Nomor: 423/Kmk.06/2002.

Mulyadi, 2010. Auditing, Salemba Empat, Jakarta.

Asna Manullang: An Analysis of The Influence of Audit Capacity Stress, Size of The Company and The Independence of Audit Committee Upon Audit Quality at Company Banking Listed on BEI (Indonesia Stock Exchange) for The Period of 2012 - 2016 
Myers, J., Myers, A. and Omer, T. C., 2003. "Exploring the term of the auditor-client relationship and the quality of earnings: A case for mandatory auditor rotation?", The Accounting Review 78, h: 779-800.

Nindita, Chairunissa, dan Sylvia Veronica Siregar, 2009. "Analisis pengaruh ukuran kantor akuntan publik terhadap kualitas audit”, Universitas Indonesia.

Nugrahanti, Yavina, 2014. "Pengaruh audit tenure, spesialisasi kantor akuntan publik, dan ukuran perusahaan terhadap kualitas audit. Skripsi. Fakultas Ekonomi, Universitas Diponegoro.

Pramudji, Sugeng dan Aprillya Trihartati, 2010. "Pengaruh independensi dan efektivitas komite audit terhadap manajemen laba (studi empiris pada perusahaan manufaktur yang terdaftar di BEI)", Jurnal Dinamika Akuntansi, Volume 2 Nomor 1.

Purwanto, Agus, 2011. "Pengaruh tipe industri, ukuran perusahaan, profitabilitas, terhadap corporate social responsibility", Jurnal Akuntansi \& Auditing, Volume 8 Nomor 1.

Purwati, Atiek Sri, 2006. "Pengaruh karakteristik komite audit terhadap ketepatan waktu pelaporan keuangan pada perusahaan publik yang tercatat di BEJ", Thesis Magister Sains Akuntansi, Fakultas Ekonomi, Universitas Diponegoro.

Santoso, Singgih, 2014. Statistik multivariat, Edisi Revisi, Elex Media Komputindo, Jakarta.

Sekaran, Uma, 2006. Research methods for business, Edisi 4, Salemba Empat, Jakarta.

Situmorang, Syafrizal Helmi dan Muslich Lufti, 2012. Analisis data untuk riset manajemen dan bisnis, USU Press, Medan.

Suryabrata, Sumadi, 2012. Metodologi penelitian, Edisi 1, Rajawali Pers, Jakarta.

Yu, D. M, 2009. Big 4 office size and audit quality. The Accounting Review, 84, h: 15211551.

ICMD (Indonesia Capital Market Directory) 2011

ICMD (Indonesia Capital Market Directory) 2012

ICMD (Indonesia Capital Market Directory) 2013

ICMD (Indonesia Capital Market Directory) 2014

ICMD (Indonesia Capital Market Directory) 2015

www.idx.co.id

Asna Manullang: An Analysis of The Influence of Audit Capacity Stress, Size of The Company and The Independence of Audit Committee Upon Audit Quality at Company Banking Listed on BEI (Indonesia Stock Exchange) for The Period of 2012 - 2016 
The Accounting Journal of BINANIAGA Vol. 03, No. 01, June 2018

PISSN: $2527-4309$

EISSN: $2580-1481$

This page intentionally be emptied.

Asna Manullang: An Analysis of The Influence of Audit Capacity Stress, Size of The Company and The Independence of Audit Committee Upon Audit Quality at Company Banking Listed on BEI (Indonesia Stock Exchange) for The Period of 2012 - 2016 